\title{
滕位置覚検查の臨床応用
}

九州労災病院整形外科
井 原 秀 俊・野 呂 純 敬
九州労災病院義肢科
三 輪 $\quad$ 恵
九州リハビリテーション大学校
高 柳 清 美

\section{Application of Position Sense in Clinical Examination of Knee Function} by

\author{
Hidetoshi Ihara and Yoshihiro Noro \\ Department of Orthopaedic Surgery, \\ Kyushu Rosai Hospital \\ Megumi Miwa \\ Section of Orthotics and Prosthetics, \\ Kyushu Rosai Hospital \\ Kiyomi Takayanagi \\ Department of Physical Therapy, \\ Kyushu Rehabilitation College
}

This study determines if an examination of knee joint position sense using electrogoniometers could serve as an indicator for one aspect of knee function. The reliability of this examination was obtained by using the test-retest method. Effects of knee problems, local anaesthesia, two different kinds of training, and knee bracing on knee position sense were evaluated. Thirty-one normal subjects and 31 patients with knee complaints were examined to investigate the influence of knee problems. The latter was also examined before and after local anaesthesia at arthroscopy. Ten students were examined before and after 8-week muscle strength training or dynamic joint control training. Another 10 students were examined before and after 8-week knee bracing. There was an impairment in joint position sense after local anaesthesia and 8-week knee bracing $(p<0.05)$. Patients with knee problems did not have impaired joint position sense. Subjects with 8-week muscle strength training and dynamic joint control training showed an enhanced joint position sense $(\mathrm{p}<0.05)$, but did not show a significant difference between these training groups. It is proposed that the examination of joint position sense of the knee could be used for evaluating knee function.

\section{は じめに}

近年, 徐々にではあるが, 関節の神経生理学的側面 が注目を浴びている。それら関節メカノレセプターか らの情報などに基づき, 姿勢制御としての関節安定化 が図られる。この機能評価の 1 側面である, 関節位置
覚の臨床応用について検討することが，本研究の目的 である。

\section{対象と方 法}

膝位置覚検査の方法は, 仰臥位にて, 膝下を手術台 下端より下垂させ, 両膝に電気角度計を装着させた。 


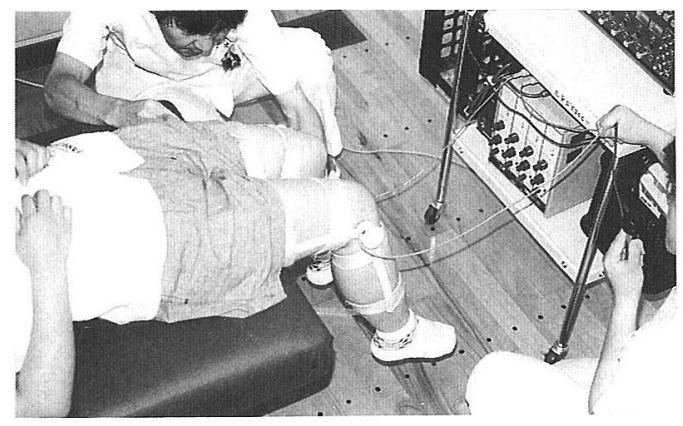

図 1 膝位置覚検查法.

両滕に電気角度計を装着し， 1 側滕の設定角に 他側膝の角度を合致させる。

被検者には閉眼，もしくは開眼で天井を見つめさせた。 設定角度として，15，30，45，60，75 の金属製の固 定角度計を作成した。この固定角度計にて, 検者が設 定する膝角度に，他側膝を合致させるように指示した (図 1 ). 施行回数は, 設定角度を 2 回ずつランダムに 含む計 10 回とした。データレコーダに記録した実験 結果をパソコンに読み出し, 設定角度と合わせ角度と の誤認角度を比較して, 対応のある $\mathrm{t}$ 検定にて統計処 理した。

本位置覚検查の検討事項として, 前提としてまず再 現性テストを行った，そのため本検査を 3 日後に同一 被検者 10 名にて実施した。

臨床応用として，以下の検討を行った。

(1) 滕疾患の影響評価

膝疾患が与える影響を評価するため，外来関節鏡を 行った 31 名の滕に愁訴を有する群（平均年齢 25 才） と, リ八大生 31 名の膝無愁訴群（平均年龄 20 才）の 比較を行った. 膝疾患群の疾患名は, 勒帯損傷 12 名, 半月損傷 8 名, 関節内部に異常のない滕痛 8 名, 滑膜 疾患 2 名, 関節軟骨損傷 1 名であった.

(2) 局麻剂の影響評価

関節メカノレセプターの関節位置覚, 特に可動域中 間帯での関与の有無を評価するため, 麻酔前と, 関節 鏡検查のための $1 \%$ ％゚゚フリン入りキシロカイン $20 \mathrm{ml}$ の関節内注入 5 分後の, 膝位置覚能を比較した. 対象は前述の膝愁訴群である.

(3) 訓練方法の効果評価

訓練種類の関節位置覚に及ばす影響を評価するため, リ八大生を, 動的関節制動訓練, 筋力訓練, 対照群の
各 10 名に分け検討した．動的関節制動訓練は 11 種類 からなる DYJOC 訓練を, 筋力訓練には Cybex II を 用い, $180^{\circ} / \mathrm{s}$ にて連続 10 回の屈伸 3 セットを, 各訓 練とも週 3 回, 8 週間に渡って行わせた.

(4) 装具の影響評価

装具装着自体が，下肢機能に与える影響を検討する ため,リ八大男子学生 11 名（平均年齢 20 才）を対象 に, 両側支柱付きサポー夕型䎑装具を装着させた。装 具を右側に 8 週間装着させ, 左膝は対照側（非装着） とした，本検査を，実験開始前の装具装着前と，装具 8 週間装着後で比較した.

\section{結果}

再現性デストでは 1 回目と 2 回目には差はなく, 再 現性があると判断した。

(1) 膝疾患の影響評価

膝愁訴群, 無愁訴群の間には, いずれの設定角度に おいても有意差はみられなかった。

(2) 局麻剤の影響評価

麻酔前後で誤認角度を比較すると, 屈曲 $15^{\circ}$ におい ては差は出なかったが, $30^{\circ}, 45^{\circ}, 60^{\circ}, 75^{\circ}$ では， 麻酰後, 誤認角の増大がみられた $(\mathrm{p}<0.05)$.

(3) 訓練方法の効果評価

動的関節制動訓練, 筋力訓練とも対照群に比して位 置覚能の改善をもたらしたが $(\mathrm{p}<0.01)$ ，両者間の 相違はなかった。

(4) 装具の影響評価

装具装着前と装着直後では差はなかった，実験開始 前と 8 週間装着後の装具装着時では，誤認角度はそれ ぞれ $6.1 \pm 1.7^{\circ} ， 9.5 \pm 3.3^{\circ}$ で差があり（ $\mathrm{p}<0.01 ）$, 実験開始前と 8 週間装着後の非装具装着時では, 誤認 角度は $6.1 \pm 1.7^{\circ} ， 9.3 \pm 4.1^{\circ}$ でこれも差があった（p $<0.05)$.

\section{考察}

関節機能は, 広義の意味では姿勢制御の一部であ る ${ }^{1}$. この姿勢制御を捉える研究 ${ }^{5)}$ は数多いが，その 測定・評価手段 ${ }^{3)}$ は多くはない，局麻前後の膝 30〜 $75^{\circ}$ 屈局位での位置覚誤認増大から, 運動中間域の関 節位置覚に関する関節の緩慢順応型メカノレセプター の貢献が示された ${ }^{2)}$ ．そうなると，膝関節構成体から 発せられる求心性情報の変調または修復は, 膝位置覚 


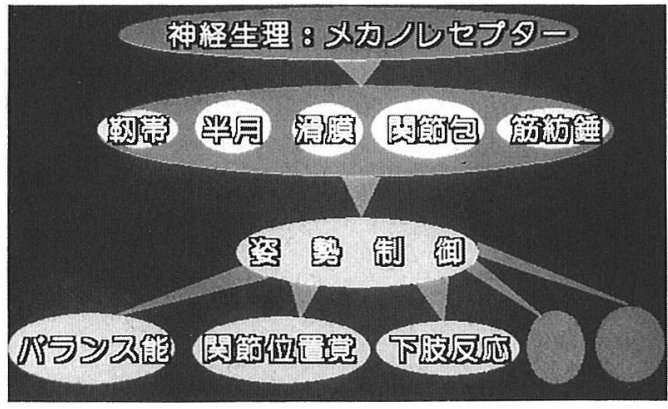

図2 関節メカノレセプターと膝位置覚検查. 脮位置覚検査は，関節メカノレセプターを介す る膝関節機能の一指標であり，広義に捉えると， 姿勢制御能の一検查でもある。

に反映し，本検査により捕えられる可能性が考えられ る (図 2 )。 それ故, 位置覚検査を, 筋力評価などと は別側面の関節機能評価として, 今後, 検討していく ことは重要であると思われる，実際，関節位置覚検査 を臨床応用した例が, 加齢影響, 人工関節置換術後機 能や予後予測, 疾病影響, 前十字靱帯損傷, 慢性足関 節捻挫, 訓練効果, 装具影響などで示されている.

本検査による検討事項評価にて, 膝疾患の影響, 局 麻剤の影響, 訓練方法の効果, 装具の影響が, 部分的 であるにせよ，一側面から評価できたことは，位置覚 検査が, 臨床的に応用できることを示唆していると考 えられよう。本検討例で，膝疾患の影響が出なかった 理由として，1）疾患自体の影響が本検査で捕らえら れる程は出なかった，2）疾患自体の影響が小さい か，またはすでに代償されていた，の 2 点が考えられ た.しかしながら， 8 週間の装具装着による本検査の 誤認增大は，同時に行った他の下肢機能検査結果 ${ }^{4)}$ と 合わせて, 装具装着による関節包の圧迫が, 関節メカ ノレセプターの求心性信号を変調することを示唆して いる.

本検查法は，(1) 電気角度計軸と大腿 - 下腿長軸間 ずれ，(2) 設定角度と電気角度計角度間ずれ，(3) 電気 角度計角度と実際角度間ずれ, (4) 左右の電気角度計 角度間ずれ，(5) 合致合図時点角度と記録時点角度間 ずれ，の諸問題を内存している. しかしながら,これ らの問題は, ある程度解決可能であり, 関節位置覚検
査が, 関節メカノレセプターの機能を表現している可 能性が大きいことを考えると，本検査は，今後，考慮 すべき膝機能評価の一側面と結論付けた.

\section{結語}

(1)電気角度計・データレコーダ・パソコンを組み合 わせたシステムにて, 設定角に対する誤認角を指標に した位置覚検査の臨床応用について検討した。

(2)検討事項として，再現性，膝疾患影響，局所麻酔 影響, 訓練効果, 膝装具影響についての評価を行った.

(3)その結果, 本検査は, 関節機能を表す指標の一側 面として, 今後考慮されてよい検査と思われた。

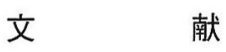

1）井原秀俊, 中山彰一 : 関節トレーニング, 協同医書, 東京, 1990 .

2）井原秀俊, 他 : 関節メカノレセプターの関節位置覚へ の関与, 膝関節麻酔による検討. 整形外科, 43:721$724,1992$.

3) 石橋敏郎, 他 : 下肢制動能の訓練・評価機器の開発. 九スポ学会誌, $4: 145-149,1992$.

4）三輪 恵, 他 : 滕装具装着が下肢機能に及ぼす影響. 日本義肢装具学会誌, $7: 117-118,1992$.

5) Nashner, L. M.: Analysis of human movement to altered environments. Trends in Neurosciences, 5 : 358-361, 1982.

\section{質 問 九州大学 三浦 裕正}

装具 8 週間装着後の位置覚低下は不可逆的な変化か.

もし回復するとすれば，どのくらいの期間で回復可 能か.

解 答 九州労災病院 井原 秀俊 不可逆性とは考えていない. 8 週経過後の再検査は 行っていないが, 同時に行ったアンケート調査では, 異和感を訴える者が1〜2週に渡り7名にみられたが， それ以後は異和感が消失しているので，そう考えた。

\section{解 答 九州労災病院 井原 秀俊}

検査自体の信頼性を確立するため, 全検査は同一検 者で行い，再現性を統計学的にみている. 